Dr. sc. Rrustem Qehaja, associated professor,

Mr. sc. Armend Ahmeti,

University of Pristina "Hasan Pristina", Faculty of Law, Kosovo

\title{
THE CONSTITUTIONAL DOUBTS ABOUT THE REQUEST FOR PROTECTION OF LEGALITY IN CIVIL LITIGATION: CASE OF KOSOVO
}

\author{
$U D K: 342$ \\ DOI: $10.31141 /$ zrpfs.2019.56.133.593 \\ Pregledni znanstveni rad \\ Primljeno: 1. 05. 2019.
}

In this article we tend to give some of our contributions about the constitutional doubts raised by the Judgement Ref. No.: AGJ.193 / 12, dated 12 April 2012, of the Constitutional Court of the Republic of Kosovo, on the use of the request for protection of legality by the state prosecutor in civil cases. We also tried to put this Judgement in a comparative relationship with the Judgement of the European Court of Human Rights, in the case GROZDANOSKI vs. The Former Yugoslav Republic of Macedonia, Application no. 21510/03, 31 May 2007. We have also attempted to give the reader some basic knowledge of the features of the request for protection of legality brought before the Supreme Court of the Republic of Kosovo by the state prosecutor, when the decision became final.

Key words: the request for protection of legality, civil litigation, state prosecutor, constitutional doubts, Supreme Court, Constitutional Court, European Court of Human Rights

\section{INTRODUCTION}

By the very fact that one certain legal relationship can't be solved between subjects of the law, respectively one subjective right of civil nature can't be realized by compromise, causes the subjects of the law to appear before the courts to solve their certain disputed issues. Each litigant, which claims that his right to a judicial process has been violated has the right to use legal remedies. Also, the Constitution of the Republic of Kosovo, inter alia, in the framework of Human Rights and Freedoms, in article 31, paragraph 1 foresees that "Everyone shall be guaranteed equal protection of rights in the proceedings before courts, other state authorities and holders of public powers".

Meanwhile, in article 32, the Constitution regulates the right to use legal remedies, where it is stated that "Every person has the right to pursue legal remedies against judicial and administrative decisions which infringe on his/her rights or interests, in the manner provided by law". Therefore, the Constitution guarantees to everyone 
the right of appeal or another legal remedy against the decision which decided upon his rights, obligations or interests based on the law. ${ }^{1}$

The croatian Professor Mihajlo Dika states that, legal remedies are procedural actions of parties or other authorised persons, which request from the competent court to annul or to change the decision of the court, pretending that the decision is unfavorable, irregular and unlawful. ${ }^{2}$

Legal remedies are divided into ordinary legal remedies and extraordinary legal remedies. Ordinary legal remedy is that legal remedy, which is allowed up to the moment when the decision becomes final in the formal sense. Even if the judgement is unlawful, if it is final in the formal sense, it can't be attacked with ordinary legal remedies.

But in these cases, the unsatisfied party can attack the judgement with extraordinary legal remedies. Extraordinary legal remedies are those legal remedies, which can be submitted after the decision becomes final in the formal sense. ${ }^{3}$

According to the Law on Contested Procedure (hereinafter: $L C P$ ) of the Republic of Kosovo, as ordinary legal remedies are known appeal against the judgement and appeal against the ruling. Whereby, extraordinary legal remedies are the revision, the proposal for repeating the procedure and the request for protection of legality.

We will focus on the legal institute of the request for protection of legality, as one of the extraordinary legal remedies, which is submitted by the state prosecutor, when the conditions provided by the law are met.

\section{OPPORTUNITY GIVE TO THE STATE PROSECUTOR TO PARTICIPATE IN CIVIL CASES VIS-À-VIS THE REQUEST FOR PROTECTION OF LEGALITY}

Opportunity is presented for certain state organs to initiate procedures of reviewing the decisions issued (the request for protection of legality). ${ }^{4}$ The request for protection of legality is one of the extraordinary legal remedies foreseen by the law in force, this legal remedy is submitted by the state prosecutor as a state organ in the name of protection of public policy. The purpose of this request is the

1 Hasani, E. and Čukalović, I. (2013). Commentary of the Constitution of the Republic of Kosovo (1st edition). Pristina: Deutsche Gesellschaft für Internationale Zusammenarbeit (GIZ) GmbH, pp. 112.

2 See also: Brestovci, F., Morina, I. and Qehaja, Rr. (hereinafter: Brestovci et al). (2017). Civil Procedural Law (1st edition). Pristina: University of Pristina "Hasan Prishtina”, Faculty of Law, pp. 397; Brestovci, F. (2006). Civil Procedural Law II (4th edition). Pristina: University of Pristina "Hasan Prishtina”, Faculty of Law, pp. 62; Janevski, A. and Zoroska - Kamilovska, T. (2009). Civil Procedural Law (1st edition). Tetovo: Faculty of Law of the South East European University, pp. 393.

3 Morina, I. and Nikçi, S. (2012). Commentary of the Law on Contested Procedure (1st edition). Pristina: Deutsche Gesellschaft für Internationale Zusammenarbeit (GIZ) GmbH, pp. 345.

4 Dika, M. (2010). Civil Procedural Law-Legal Remedies (10th edition). Zagreb: Narodne Novine, p. 3. 
establishment of legality, which was violated by the final decision which violates the law. ${ }^{5}$

In civil litigation the role of the state prosecutor is limited. He can only: 1) initiate some judicial proceedings only when this is expressly foreseen by the law, 2) intervene in proceedings between third parties for protection of public interest, 3 ) submit extraordinary legal remedies and 4) request postponent or suspension of enforcement. ${ }^{6}$

In this regard, we must state that the state prosecutor for a long time hasn't been included in civil litigation in Germany; in Austria he can only raise the claim for divorce. By contrast, his participation in civil cases in the francophone legal systems is commonplace. ${ }^{7}$

The request for protection of legality was introduced after the World War II into Croatian law as a result of the reception of Soviet law, and was clearly motivated by the doctrine of (socialist) state paternalism and the protection of State ("public") interests in private law disputes. ${ }^{8}$ This legal remedy in Croatian law was abolished by Amendments to the Code of Civil Procedure that happened in 2003. Authors think that this is the biggest change in the legislation of Croatia, regarding the extraordinary legal remedies. The official explanation for deleting the rules on the request for protection of legality was the "removal of State controls" in civil proceedings, but it also pointed to some practical problems that had been caused by the fusion of the services of the State Defender's Office (the State Attorney who represents the State as a party to civil proceedings) with the service of public prosecution and the representation of public, general interests in all types of cases. ${ }^{9}$

Further more, even the Federation of Bosnia and Herzegovina has abolished this extraordinary legal remedy. This conclusion is derived by analyzing the legal provisions of the Law on Contested Procedure (no. 53/03, 98/15). ${ }^{10}$

In this regard, Slovenia didn't abolish this extraordinary legal remedy. This conclusion is derived by analyzing the legal provisions of the Law No. 36/04 on Contested Procedure ${ }^{11}$ and the Law No. 710-01/95-4/72 on Amending and Supplementing the Law No. 36/04 on Contested Procedure. ${ }^{12}$ 333.

5 Poznić, B. (1987). Civil Procedural Law (10th edition). Belgrade: Savremena Administracija, pp.

6 Jakšić, A. (2015). Civil Procedural Law (8th edition). Belgrade: University of Belgrade, Faculty of Law, pp. 121.

7 Loc. cit.

8 https://www.bib.irb.hr/195152, accessible at 14 November 2018, time 15:00 pm.

9 Loc. cit.

10 Official Gazette of the Federation of Bosnia and Hercegovina (hereinafter: $F B i H$ ), No. 53/03, which entered into force on 05 November 2003. (Official Gazette of the FBIH, No. 73/05, 19/06) and the Law on Amendments to the Law on Contested Procedure (Official Gazette of the FBiH, No. 98/15 of 23 December 2015).

11 Official Gazette of the Republic of Slovenia, No. 36/04. The provisions of Articles 1, 2, 8, 9, 10 , 11, 12 and 13 of this Act shall become applicable on 1 May 2004. This Act shall enter into force on the fifteenth day following its publication in the Official Gazette of the Republic of Slovenia.

12 Official Gazette of the Republic of Slovenia No. 710-01/95-4/72, Ljubljana, 25 April 2008. The present Act shall come into effect on 1 October 2008. 
In addition to what was said above, in we analyze the legislation of Hungary, it is worth mentioning the Decision No. 1/1994. (I.7.) AB of the Constitutional Court. This decision meant a new step on the way toward the renewal of the remedy system. This decision sharply defined the right to disposition of the parties and limited the role of the state prosecutor (in order to meet the requirement of the rule of law). The Constitutional Court found that the prosecutor's general powers to initiate proceedings, to intervene, to file appeals and submit motions for the review of final decisions were unconstitutional. Therefore the Constitutional Court annulled legislative provisions pertaining to the exercise of the above powers. ${ }^{13}$

If we go back to national legislation analysis, respectively in the legislation of the Republic of Kosovo, we must emphasize that the Law on State Prosecutor ${ }^{14}$ has determined the duties and the competencies of state prosecutors, which include submitting ordinary and extraordinary legal remedies against decisions of courts. Also, with the Law on Amending and Supplementing the Law on State Prosecutor ${ }^{15}$ it is foreseen that "Chief State Prosecutor has the exclusive competence for cases in third instance before the Supreme Court of the Republic of Kosovo and above all, cases which include extraordinary legal remedies" ${ }^{16}$ This means for all areas of court proceedings, including also the civil litigation. This law gives competence to the state prosecutor to submit the request for protection of legality in civil litigation, as an extraordinary legal remedy, according to the legal provisions of the LCP. Also, the Law on Courts ${ }^{17}$ has determined the competence of courts to decide based on the requests for protection of legality. The Supreme Court is competent to adjudicate the requests for protection of legality against final decisions of the courts of the Republic of Kosovo, as provided by the law. ${ }^{18}$

\section{SOME OF THE TYPICAL FEATURES OF USAGE OF THE REQUEST FOR PROTECTION OF LEGALITY IN CIVIL CASES}

The request for protection of legality is expressly regulated by Articles 245-251 of the LCP of the Republic of Kosovo. The request for protection of legality is

13 Harsági, V. (2007). Developement of the system of legal remedies in Hungarian civil procedural law after the democratic tranformation. Budapest: Journal "Iustum Aequum Salutare” of the Pazmany Peter Catholic University, no. 3, pp. 47.

14 Law No. 03/L -225 on State Prosecutor of the Republic of Kosovo (hereinafter: LSP), 30 September 2010. Articles 21, 28 and 29 shall enter into force as provided in Article 80(6) of the Constitution of the Republic of Kosovo. The remaining part of this law shall enter into force on 1 January 2013.

15 Law No. 05/L -034 on amending and supplementing the LSP of the Republic of Kosovo, 28 May 2015. This Law shall enter into force fifteen (15) days after the publication in the Official Gazette of the Republic of Kosovo.

16 Article 7, paragraph 1.9 of the LSP of the Republic of Kosovo and Article 11, paragraph 1.4 of the Law on Amending and Supplementing the LSP of the Republic of Kosovo.

17 Law No. 03/L-199 on Courts of the Republic of Kosovo, 22 July 2010, Promulgated by the Decree No. DL-047-2010, dated 09 August 2010, of the President of Republic of Kosovo, Dr. Fatmir Sejdiu. This Law shall enter into force on January 1, 2011 for Articles 29, 35, 3638 and 40, while for other Articles it shall begin to be implemented from 1 January 2013.

18 Ibidem, Article 22, paragraph 1, subparagraph 1.1. 
submitted to the court which decided in the first instance, in sufficient number of copies for court and for parties.

Against the final decision, the state prosecutor can submit the request for protection of legality within three (3) months. The deadline for submitting the request for protection of legality is calculated:

a. against the decision taken in the first instance, against which there was made no appeal, from the day this decision could be opposed by appeal;

b. against the decision taken in the second instance, against which is raised the revision, from the day this decision was taken to the party delivered at the latest. ${ }^{19}$

Against the decision issued in the second instance, against which the parties have raised the revision, the state prosecutor might submit the request for protection of legality only within thirty (30) days, from the date the revision was delivered to that party, the revision of which was sent earlier. ${ }^{20}$

The filing of the request for protection of legality does not postpone the execution of the decision, but the postponement can be achieved according to the provisions of the enforcement procedure. ${ }^{21}$

The request for protection of legality is not allowed against the decision issued by the Supreme Court, which decided on the revision or on the request for protection of legality. ${ }^{22}$

The request for protection of legality is submitted by the state prosecutor, in accordance with the law. ${ }^{23}$

Even the new legislator during the drafting of the new LCP had considered this fact and initially removed this legal remedy from the regulation. At the end of the drafting procedure, this legal remedy was introduced again into the LCP. The motives of the legislator for this uncertainty during the phase of drafting the new LCP are, so far, unknown. Therefore, even in our case it can be concluded that, despite the unsuccessful wording of the LCP provisions regarding the request

19 Article 245, paragraph 1 of the LCP of the Republic of Kosovo.

20 Ibidem, Article 245, paragraph 2.

21 Poznić, B., op. cit., pp. 333; Stanković, G. (1990). Civil Procedural Law (1st edition). Belgrade: Institute for Textbooks and Teaching Resources, pp. 370; Starović, B and Keča, R. (2004). Civil Procedural Law (2nd edition). Novi Sad: University of Novi Sad, Faculty of Law, pp. 440; Gajović, J. (1998). The Law on Contested Procedure with Commentary and Court Practice (1st edition). Belgrade: Public Company "Službeni Glasnik”, pp. 305. See also: articles 60, 61 and 62 of the Law no. 04/L139 on Enforcement Procedure of the Republic of Kosovo, 20 December 2012, Promulgated by Decree No. DL-001-2013, dated 03 January 2013, by the President of the Republic of Kosovo, Atifete Jahjaga. Articles from 323 through 396 of this Law shall enter into force and shall be applied fifteen (15) days after publication in the Official Gazette. Other provisions of this law shall enter into force on 1 January 2014.

22 Article 245, paragraph 3 of the LCP of the Republic of Kosovo in relation to the Article 12 of the Law no. 04/L-118 on Amending and Supplementing the LCP of the Republic of Kosovo, 13 September 2012, Promulgated by Decree No. DL-045-2012, dated 28 September 2012, by the President of the Republic of Kosovo Atifete Jahjaga. This Law shall enter into force fifteen (15) days after its approval in the Official Gazette of the Republic of Kosovo.

${ }^{23}$ Article 246 of the LCP of the Republic of Kosovo. 
for protection of legality, these provisions have a taxative character. And it's hard for any other interpretation to may come into the light. Even if it comes to any other interpretation to allow another cause not foreseen by the law, then the very narrow interpretation of the provisions regarding the reasons for filing the request for protection of legality is indispensable. ${ }^{24}$

Therefore, the state prosecutor is the only person that has the real and procedural legitimacy of raising the request for protection of legality. The state prosecutor has this exclusive right, even in cases where as party is presented the state prosecutor. Irrelevant is the question of whether the request for protection of legality can be submitted against the will of the party, due to the fact that in practice it never happens that this extraordinary legal remedy is submitted without the request of the party. Another requirement for submitting the request for protection of legality is that the case has been ended by final decision. ${ }^{25}$

However, the initiative for submitting the request for protection of legality can also be taken by the parties, which under the conditions of the impossibility of submitting this extraordinary legal remedy, propose to the prosecutor to do so. In the court practice, this happens usually, so that the request for protection of legality is submitted by the prosecutor after he/she has taken the initiative from the parties. ${ }^{26}$

The state prosecutor can raise the request for protection of legality for these reasons:

a. for essential violation of provisions of the contested procedure, if the violation has to do with territorial competence, if the court of the first instance has issued the decision without holding the main hearing, while it was its duty to hold the main hearing, if it has decided for the request, on which the contestation is continuing, or if in contradiction with the law, the public is excluded from the main hearing;

b. for wrong application of the material law. ${ }^{27}$

The state prosecutor can't raise the request for protection of legality due to the exceeding of the claim and due to the wrong or incomplete determination of the factual situation. ${ }^{28}$

The request for protection of legality, therefore, is conceived to provide control of legality only in the viewpoint of law, but not in the factual viewpoint. ${ }^{29}$

Free evaluation of the evidence can't be subject of the request for protection of legality raised by the state prosecutor. In this regard, it's interesting to cite

24 Morina, I. and Nikçi, S., op. cit., pp. 443, 448.

25 Ibidem, pp. 444.

26 Shala, M., Zogaj, A., Totaj, V. and Leku, Z (hereinafter: Shala et al). (2015). Handbook of Judges on Contested Procedure. Pristina: Kosovo Judicial Institute, pp. 142.

27 Article 247, paragraph 1, subparagraph a) and b) of the LCP of the Republic of Kosovo.

28 Ibidem, Article 247, paragraph 2; Shala et al, op. cit., pp. 142; The Supreme Court of Serbia, Gžž. 275/74 cited in Krsmanović, T. (2002). Litigation in Practice - Principal attitudes, Conclusions, Legal opinions and Sentences from the Civil Litigation (1st Edition). Belgrade: Poslovni biro, pp. 291.

29 Starović, B. and Keča, R., op. cit., pp. 442. 
the Judgement Gžž-23/69 of the Supreme Court of the Former Socialist Federal Republic of Yugoslavia, in which it is said, inter alia, that "In cases when the authorized state prosecutor raises the request for protection of legality and in it, points out that there is a reasonable doubt about the truth based on which the final judgement is issued - he is obliged to state the reasons why he finds that there is a reasonable doubt of the truthfulness of the facts mentioned." 30

Based on the provisions of the LCP, the competent court in order to decide for the request for protection of legality, shall act even when concludes that there was essential violation of provisions of the contested procedure, that was done in the procedure before the court of the first instance. ${ }^{31}$

If against the same decision also the revision is raised (except the request for protection of legality), the competent court shall decide on these extraordinary legal remedies with one decision. ${ }^{32}$

Meanwhile, article 251 of the LCP determines that, when the court decides upon the request for protection of legality, it will be limited only in examining the violations that the state prosecutor points out in its request. The authors of the Commentary of the LCP of the Republic of Kosovo state that "The Supreme Court can examine the case ex-officio even for other reasons, at least this examination isn't prohibited by legal norms." 33

But, in the legal doctrine, there are also other opinions, which differ from the one stated above. E.g Professor Emeritus of Civil Procedure Faik Brestovci thinks that "The attacked Judgement or Ruling is examined only in the attacked part by the request for protection of legality. The court takes into account only the reasons expressly shown in the request for protection of legality. The request for protection of legality which does not contain its reasons is dismissed."

In this case, by taking into account the fact that the request for protection of legality is an extraordinary legal remedy of attacking the final decision, then it can be ascertained that this remedy has no suspensive effect and as a result of this situation, the decision can be enforced in the enforcement procedure. Despite the fact that there are no reference provisions, I think that the provisions of the revision procedure (Articles 212, 213, 216, 220, 221, 222, 223 of the LCP of the Republic of Kosovo) should be applied analogously to the procedure of the request for protection of legality. It is clear that these provisions can be applied only analogously, unless something else is foreseen with the legal provisions which regulate the request for protection of legality. ${ }^{34}$

30 Cited in Ralčić, T. and Tanasković, V. (1980). The Law on Contested Procedure with Commentary, Court Practice, Forms and Registry of Terms (2nd edition). Belgrade: Newspaper publishing work organization "Književne novine”, pp. 649.

31 Article 248 of the LCP of the Republic of Kosovo.

32 Ibidem, Article 249.

33 Morina, I and Nikçi, S., op. cit., pp. 451

34 Brestovci et al, op. cit., pp. 451; Zuglia, S. (1957). Civil Procedural Law of the Federal people of the Republic of Yugoslavia (1st edition). Zagreb: Publishing Company “Školska Knjiga”, pp. 570 and 572. 
The Supreme Court decides for the annulment of the final decision of the first instance court or the second instance court, in whole or in part, and returns the case for re-trial at the first instance court or the second instance court, if after the evaluation of the claims stated in the request the court finds that there has been procedural or material violation of the law.

Here it's presented one case, where the request for protection of legality was approved and the court decided to annul the decisions of the first instance court and the second instance court. Damage compensation was the subject of the dispute. The Supreme Court with the Ruling CML. No. 13/2012, dated 11 December 2012, accepted the request for protection of legality submitted by the state prosecutor and annuled the Judgement of the District Court of Peja AC. No. 329/11, dated 05 March 2012 and the Judgement of the Municipal Court of Peja C. No. 7/2009, dated 17 June 2011, and the case was returned to the first instance court for retrial. According to the Supreme Court's assessment, the first instance court wrongly applicated the material law, because the factual situation of the case has not been fully determined. Thus, the findings of the first instance court which were fully approved by the second instance court are not enough for the fair and lawful resolution of this dispute. The Court of Appeal of the Republic of Kosovo, while deciding regarding the appeal of the defendant party has been obliged by the law, to take care of the right application of the material law. The Supreme Court of the Republic of Kosovo, having in regard the claims of the request for protection of legality, based on Article 247, paragraph 1, point b) and Article 251 of the LCP, had return the case for re-trial at the first instance court, respectively the first instance court was obliged to avoid the defects highlighted in this judgement, to engage the relevant Railway Expert, which is specialized for railway accidents, to verify the liability of the defendant party "NHT - Kosovo Railways", to verify the obligation of the defendant party regarding the establishment of the barriers or the Ministry of Transport and Post Telecommunication of the Republic of Kosovo and the fact that, if there had been foreseen to establish the barriers at the critical location where the accident occured. ${ }^{35}$

Further more, The Supreme Court with the Ruling CML. No. 9/2015, dated 17 December 2015, accepted the request for protection of legality raised by the state prosecutor and annuled the Ruling of the Court of Appeal AC. No. 719/12015, dated 06 August 2015, and the case was returned for re-trial at the second instance court (Court of Appeal). The state prosecutor has presented essential violations of procedural provisions of the LCP, based on Article 182, which have occured at the procedure of appeal before the Court of Appeal, that the Court of Appeal unjustly decided to accept the appeal by wrongly calculating the legal deadline for submitting the appeal. The Court of Appeal of the Republic of Kosovo, after the acceptance of the appeal of creditor, has unjustly applicated the legal provisions regarding the calculating of the legal deadline for submitting the appeal and this

35 The Ruling of the Supreme Court of the Republic of Kosovo, CML. No. 13/2012, dated 11 December 2013. 
has influenced in issuing an unjust and unlawful court decision, due to the fact that the appeal of the creditor is submitted after the expiration of the legal deadline. The Supreme Court decided that the second instance court (Court of Appeal) had wrongly applicated the material law. Due to the fact that, the factual situation was not fully determined and for this reason, consequently there were no conditions for changing the attacked decision by the Supreme Court. The Supreme Court assessed that the creditor had submitted the appeal after the expiration of the legal deadline. The Supreme Court obliged the second instance court (Court of Appeal) to avoid the defects, to assess the timeliness of the appeal submitted against the Ruling of the first instance court according to the evidence found in the court file and then, issue a just and a lawful decision. ${ }^{36}$

The Supreme Court will refuse the request for protection of legality as unfounded, if the claims of the state prosecutor don't present violations of the applicable law in its request. The state prosecutor can't raise the request for protection of legality for wrong or incomplete verification of the factual situation. The state prosecutor can't give an assessment on factual situation, because this presents violation of the law. The request for protection of legality must be based on material and procedural violations of the law.

The Supreme Court will dismiss the request for protection of legality in these cases: when the request for protection of legality is not allowed, when the request for protection of legality is submitted by non authorised persons respectively not by the competent state prosecutor. It must be stated that, the request for protection of legality can't be used against the decisions of the Supreme Court.

If from the content of the request for protection of legality raised by the state prosecutor derives only the attacked judgement, but not any violation of the law is pointed out, then according to this request the Supreme Court can't decide and this request, must be dismissed as not allowed. ${ }^{37}$

When the legal deadlines for submitting the request for protection of legality are not respected from the state prosecutor, respectively when the Supreme Court finds that the request for protection of legality is submitted out of legal deadline foreseen in Article 245 of the LCP of the Republic of Kosovo, then dismisses the request as untimely. The calculation of legal deadlines (the beginning of deadline, the termination of deadline etc.) is done according to the Article 126 of the LCP. ${ }^{38}$

36 The Ruling of the Court of Appeal of the Republic of Kosovo, Ac. No. 719/2015, dated 06 August

37 The Supreme Court of Serbia, Gžž. 388/72, cited in Krsmanović, T., op. cit., pp. 290; Gajović, J., op. cit., pp. 308; the Ruling of the Supreme Court of Cassation of Serbia, Gzz1 103/2015, dated 02 December 2015.

38 Morina, I. and Nikçi, S., op. cit., pp. 263-264. 


\section{THE REQUEST FOR PROTECTION OF LEGALITY VIS-À-VIS CONSTITUTIONAL DOUBTS OF ITS USAGE IN CIVIL LITIGATION}

According to the Article 250 of the LCP of the Republic of Kosovo, the court informs only the state prosecutor regarding the main hearing of the case, when the state prosecutor raises the request for protection of legality. Only the state prosecutor will be summoned at the hearing of the court for hearing the case upon the request for protection of legality. According to this legal provision, at this session won't be summoned none of the parties, neither the winner or the loser party. Also, according to this legal provision, the request for protection of legality has the character of an unilateral legal remedy. Through this legal provision it may have flagrant violation of procedural provisions, especially for the fact that it roughly violates the main principle of hearing the opposing party. It's also problematic the fact that for this extraordinary legal remedy, the real and the procedural legitimacy is only decided for the state prosecution. ${ }^{39}$

The problem is further complicated by the Judgement of the Constitutional Court of the Republic of Kosovo Ref. No.: AGJ.193 / 12, dated 12 April 2012. Reasonable constitutional doubts are fully and clearly argumented by the 9 (nine) Constitutional Judges of the Constitutional Court of the Republic of Kosovo in the cited Judgement above. None of the Judges used his right to issue a dissenting opinion. ${ }^{40}$

The Applicant claimed that the challenged decision had violated his rights guaranteed by Articles 3, paragraph 2 (Equality Before the Law), Article 24, paragraph 1 (Equality Before the Law) and Article 31 (Right to Fair and Impartial Trial) of the Constitution of the Republic of Kosovo and Article 6 of the European Convention for the Protection of Human Rights and Fundamental Freedoms. The Applicant complained, in particular, that the Supreme Court rendered a judgment without the Applicant having been notified and summoned to take part in the proceedings in the same way as the state prosecutor. Inter alia, in this judgement it's stated that the Applicant could not have exercised his right to a fair trial without being present at these proceedings before the Supreme Court. The Court further notes that, according to the submissions of the Applicant, the Supreme Court's Judgment of 3 September 2010, was rendered in the presence of the Public Prosecutor, but without the Applicant having being notified and summoned to take part in the proceedings in the same way as the Public Prosecutor. Thus, in the Applicant's

39 Ibidem, pp. 443.

40 Article 61 of the Rules of Procedure of the Constitutional Court of the Republic of Kosovo, no. 01/2018, Adopted on 31 May 2018, expressly states that "A Judge of the Court shall have the right to prepare a written dissenting opinion to a Judgment of the Court. A dissenting opinion may be joined by other Judges and shall state specifically the reasons why the Judge disagrees with the opinion of the majority or plurality of the Court" and Article 63, paragraph 2, expressly states that "All dissenting opinions shall be an integral part of the Judgment and shall be published together with and at the same time as the Judgment of the Court”. See also: Mushkolaj, Gj., Morina, V. and Lamoen van, L. (2014). Commentary of the Law for the Constitutional Court of the Republic of Kosovo (1st edition). Pristina: Deutsche Gesellschaft für Internationale Zusammenarbeit (GIZ) GmbH, pp. 167-169. 
opinion, the Supreme Court had not treated him equally and had, therefore, violated his right to a fair trial, as guaranteed by Article 31 of the Constitution and Article 6 of the Convention for the Protection of Human Rights and Fundamental Freedoms. Therefore, by not notifying the Applicant of the request for protection of legality lodged by the State Prosecutor and by not inviting him as a party to the proceedings before the Supreme Court, the Supreme Court, in its Judgment of 03 September 2010, infringed the Applicants' right to a fair trial under Article 31 of the Constitution and Article 6 (1) of the Convention for the Protection of Human Rights and Fundamental Freedoms. The Constitutional Court unanimously stated that there has been a breach of Article 31 (Right to Fair and Impartial Trial) of the Constitution, in conjunction with Article 6 (1) (Right to Fair Trial) of the Convention for the Protection of Human Rights and Fundamental Freedoms, meanwhile declared null and void the Judgment of the Supreme Court of the Republic of Kosovo, Rev. No. 406/2008 of 03 September 2010.

Further more, the Constitutional Court remanded the Judgment to the Supreme Court for reconsideration in conformity with the judgment of this Court. This Judgement is published at the Official Gazzette of the Republic of Kosovo ${ }^{41}$ and it's translated in 4 (four) different foreign languages: English, Serbian, Turkish and Bosnian. We must emphasize that, according to Article 116, paragraph 1 of the Constitution of the Republic of Kosovo, the decisions of the Constitutional Court are binding for the judiciary and all persons and institutions of the Republic of Kosovo. Decisions of the Constitutional Court can not be subject to regular judicial review by regular courts or any other institution. The decisions of the Constitutional Court are effective immediately. ${ }^{42}$ We must also notice that, according to Article 53 of the Constitution of the Republic of Kosovo "Human Rights and Fundamental Freedoms guaranteed by this Constitution shall be interpreted consistent with the court decisions of the European Court of Human Rights". In this regard, we must point out the Case GROZDANOSKI v. THE FORMER YUGOSLAV REPUBLIC OF MACEDONIA, Application no. 21510/03, 31 May $2007^{43}$, which is related to the Judgement of the Constitutional Court cited above. According to the factual situation of the Case GROZDANOSKI v. THE FORMER YUGOSLAV REPUBLIC OF MACEDONIA it derives that, inter alia, the Applicant complained under Article 6 of the Convention for the Protection of Human Rights and Fundamental Freedoms that the proceedings before the Supreme Court were unfair. In particular, he argued that the principle of equality of arms had been violated as he had not been given an opportunity to comment on the company's appeal on points of law and the state prosecutor's request for the protection of legality. He further complained that the Supreme Court had incorrectly applied the national law.

41 https://gzk.rks-gov.net/ActDetail.aspx?ActID=3102, accessible at 15 October 2018, time 15:00 pm.

42 Hasani, E. and Čukalović, I., op. cit., pp. 606-607.

43 http://echr.ketse.com/doc/21510.03-en-20070531/view/, accessible at 15 October 2018, time 15:00 pm. 
The European Court of Human Rights in consisting of 7 (seven) judges, inter alia, unanimously holded that "There has been a violation of the principle of equality of arms under Article 6 \& 1 of the Convention for the Protection of Human Rights and Fundamental Freedoms". Further more, according to the court's assessment, Article $6 \S 1$ of the Convention for the Protection of Human Rights and Fundamental Freedoms is intended, above all, to secure the interests of the parties and those of the proper administration of justice. In the present case, respect for the right to a fair trial, guaranteed by Article $6 \S 1$ of the Convention for the Protection of Human Rights and Fundamental Freedoms, required that the applicant be given an opportunity to have knowledge of, and to comment upon the company's appeal and the state prosecutor's request, which didn't happen.

From the above mentioned analyzes, it derives the inevitable high dose of constitutional suspicion for the request for protection of legality, in cases when only the state prosecutor is summoned to give his assessments about the request for protection of legality which he/she personally submitted. The Judges of the Supreme Court of the Republic of Kosovo must be very careful and in these cases, besides the state prosecutor, the opposing party should also be invited to participate at the courts hearing about the request for protection of legality submitted by the state prosecutor. If the invitation is not sent to the opposing party, and the opposing party does not participate at the hearing, then there is a risk of violation of the Article 31 of Constitution of the Republic of Kosovo and Article 6 of the Convention for the Protection of Human Rights and Fundamental Freedoms.

\section{CONCLUSIONS}

From the legal provisions of the LCP of the Republic of Kosovo, we conclude that the request for protection of legality is an extraordinary legal remedy of attacking the decisions issued in civil litigation, which is exercised from the competent state prosecutor, based on the reasons expressly regulated by the law and within the deadline foreseen strictly by the law. In spite of this, we must say that the role of the state prosecutor in civil litigation is fading in states with modern legal systems. From our analysis, it derives that the request for protection of legality raised by the state prosecutor in civil cases, is abolished from the positive law (Law on Contested Procedure) of Hungary, Croatia, Bosnia and Hercegovina, even in Kosovo's legislation initially this extraordinary legal remedy was removed, but in the phase of drafting the law (Law on Contested Procedure), under unclear circumstances, this legal institute was re-introduced. The reasons why this legal institute came back and was re-introduced to the drafting phase of the LCP are until now uknown.

However, when talking about this legal institute, special attention deserves the Judgement Ref. No.: AGJ. 193 / 12, dated 12 April 2012, of the Constitutional Court of the Republic of Kosovo, which treats some constitutional issues of this extraordinary legal remedy used in civil litigation. From this Judgement derives 
that, if only the state prosecutor is summoned to the courts hearing regarding the request for protection of legality, meanwhile the opposing party is not summoned to the courts hearing to express his/her claims, opinions and arguments, respectively is not heared from the court, then these cases of neglection may cause violation of the Article 31 of the Constitution of the Republic of Kosovo in relation with the Article 6 of the Convention for the Protection of Human Rights and Fundamental Freedoms. So in these cases, Article 250 of the LCP of the Republic of Kosovo, should always be interpreted extensively, so that also the opposing party must be summoned to the courts hearing regarding the request for protection of legality brought before the Supreme Court of the Republic of Kosovo by the state prosecutor, besides the state's prosecutor.

So as a conclusive remark, the Supreme Court of the Republic of Kosovo should invite also the opposing party, besides the competent state prosecutor at the courts hearing regarding the request for protection of legality, in other words the Supreme Court should give the opportunity also to the opposing party to give their response regarding to the claims raised on the request for protection of legality.

\section{References}

1. Brestovci, F. (2006). Civil procedural law II (4th edition). Pristina: University of Pristina "Hasan Prishtina", Faculty of Law;

2. Brestovci, F., Morina, I. and Qehaja, Rr. (2017). Civil Procedural Law (1st edition). Pristina: University of Pristina "Hasan Prishtina", Faculty of Law;

3. Morina, I., \& Nikçi, S. (2012). Commentary of the Law on Contested Procedure. Pristina: Deutsche Gesellschaft für Internationale Zusammenarbeit (GIZ);

4. Hasani, E. and Čukalović, I. (2013). Commentary of the Constitution of the Republic of Kosovo (1st edition). Pristina: Deutsche Gesellschaft für Internationale Zusammenarbeit (GIZ) GmbH;

5. Janevski, A. and Zoroska - Kamilovska, T. (2009). Civil Procedural Law (1st edition). Tetovo: Faculty of Law of the South East European University;

6. Dika, M. (2010). Civil Procedural Law - Legal Remedies (10th edition). Zagreb: Narodne Novine;

7. Poznić, B. (1987). Civil Procedural Law (10th edition). Belgrade: Savremena Administracija;

8. Jakšić, A. (2015). Civil Procedural Law (8th edition). Belgrade: University of Belgrade, Faculty of Law;

9. Harsági, V. (2007). Developement of the system of legal remedies in Hungarian civil procedural law after the democratic tranformation. Budapest: Journal "Iustum Aequum Salutare" of the Pazmany Peter Catholic University, no. 3;

10. Stanković, G. (1990). Civil Procedural Law (1st edition). Belgrade: Institute for Textbooks and Teaching Resources; 
11. Starović, B and Keča, R. (2004). Civil Procedural Law (2nd edition). Novi Sad: University of Novi Sad, Faculty of Law;

12. Gajović, J. (1998). The Law on Contested Procedure with Commentary and Court Practice (1st edition). Belgrade: Public Company "Službeni Glasnik";

13. Shala, M., Zogaj, A., Totaj, V. and Leku, Z. (2015). Handbook of Judges on Contested Procedure. Pristina: Kosovo Judicial Institute;

14. Krsmanović, T. (2002). Litigation in Practice - Principal attitudes, Conclusions, Legal opinions and Sentences from the Civil Litigation (1st edition). Belgrade: Poslovni biro;

15. Ralčić, T. and Tanasković, V. (1980). The Law on Contested Procedure with Commentary, Court Practice, Forms and Registry of Terms (2nd edition). Belgrade: Newspaper publishing work organization "Književne novine”;

16. Zuglia, S. (1957). Civil Procedural Law of the Federal people of the Republic of Yugoslavia (1st edition). Zagreb: Publishing Company "Školska Knjiga”;

17. Mushkolaj, Gj., Morina, V. and Lamoen van, L. (2014). Commentary of the Law for the Constitutional Court of the Republic of Kosovo (1st edition). Pristina: Deutsche Gesellschaft für Internationale Zusammenarbeit (GIZ) GmbH;

18. Law no. 04/L-139 on Enforcement Procedure of the Republic of Kosovo, 20 December 2012, Promulgated by Decree No. DL-001-2013, dated 03 January 2013, by the President of the Republic of Kosovo, Atifete Jahjaga;

19. Law No. 03/L -225 on State Prosecutor of the Republic of Kosovo, 30 September 2010;

20. Law No. 05/L -034 on Amending and Supplementing the Law No. 03/L-225 on State Prosecutor of the Republic of Kosovo, 28 May 2015;

21. Law No. 03/L-006 on Contested Procedure of the Republic of Kosovo;

22. Law no. 04/L-118 on Amending and Supplementing the Law No. 03/L-006 on Contested Procedure of the Republic of Kosovo, 13 September 2012, Promulgated by Decree No. DL-045-2012, dated 28 September 2012, by the President of the Republic of Kosovo Atifete Jahjaga;

23. Law No. 03/L-199 on Courts of the Republic of Kosovo, 22 July 2010, Promulgated by the Decree No. DL-047-2010, dated 09 August 2010, of the President of Republic of Kosovo, Dr. Fatmir Sejdiu;

24. The Rules of Procedure of the Constitutional Court of the Republic of Kosovo, no. 01/2018, Adopted on 31 May 2018;

25. Official Gazette of the Federation of Bosnia and Hercegovina, No. 53/03;

26. Official Gazette of the Federation of Bosnia and Hercegovina, No. 73/05, 19/06;

27. Official Gazette of the Federation of Bosnia and Hercegovina, No. 98/15 of 23 December 2015;

28. Official Gazette of the Republic of Slovenia, No. 36/04;

29. Official Gazette of the Republic of Slovenia No. 710-01/95-4/72;

30. The Ruling of the Supreme Court of the Republic of Kosovo, CML. No. 13/2012, dated 11 December 2013; 
31. The Ruling of the Court of Appeal of the Republic of Kosovo, Ac. No. 719/2015, dated 06 August 2015;

32. The Supreme Court of Serbia, Gžž. 275/74;

33. The Supreme Court of Serbia, Gžž. 388/72;

34. The Ruling of the Supreme Court of Cassation of Serbia, Gzz1 103/2015, dated 02 December 2015.

35. https://www.bib.irb.hr/195152, accessible at 14 November 2018, time 15:00 pm;

36. http://echr.ketse.com/doc/21510.03-en-20070531/view/, accessible at 15 October 2018, time 15:00 pm.

\section{USTAVNE DVOJBE O ZAHTJEVU ZA ZAŠTITU ZAKONITOSTI U GRAĐANSKIM PARNICAMA: SLUČAJ KOSOVO}

Članak je prilog raspravi o ustavnim dvojbama koje je pokrenula Presuda br. Br .: AGJ.193 / 12, od 12. travnja 2012., Ustavnog suda Republike Kosovo, o korištenju zahtjeva za zaštitu zakonitosti od strane državnog tužitelja u građanskim predmetima. Autori su pokušali staviti ovu presudu u komparativni odnos s presudom Europskog suda za ljudska prava, u slučaju poznatom kao Grozdanski protiv Bivše Jugoslavenske Republike Makedonije, prijava br. 21510/03, 31. svibnja 2007. Također se daju neka osnovna saznanja o značajkama zahtjeva za zaštitu zakonitosti kojeg je državni tužitelj podnio Vrhovnom sudu Republike Kosovo.

Ključne riječi: zahtjev za zaštitu zakonitosti, parnica, državni tužitelj, ustavne dvojbe, Vrhovni sud, Ustavni sud, Europski sud za ljudska prava 